\title{
The role of vascular endothelial growth factor receptor-1 signaling in compensatory contralateral lung growth following unilateral pneumonectomy
}

\author{
Yoshio Matsui ${ }^{1}$, Hideki Amano ${ }^{1,2}$, Yoshiya Ito ${ }^{3}$, Koji Eshima ${ }^{4}$, Hideaki Tamaki ${ }^{5}$, Fumihiro Ogawa ${ }^{1}$, Akira Iyoda ${ }^{6}$, \\ Masafumi Shibuya ${ }^{7}$, Yuji Kumagai ${ }^{2}, Y_{\text {Kukitoshi Satoh }}{ }^{6}$ and Masataka Majima ${ }^{1}$
}

Compensatory lung growth models have been widely used to investigate alveolization because the remaining lung can be kept intact and volume loss can be controlled. Vascular endothelial growth factor (VEGF) plays an important role in blood formation during lung growth and repair, but the precise mechanisms involved are poorly understood; therefore, the aim of this study was to investigate the role of VEGF signaling in compensatory lung growth. After left pneumonectomy, the right lung weight was higher in VEGF transgenic mice than wild-type (WT) mice. Compensatory lung growth was suppressed significantly in mice injected with a VEGF neutralizing antibody and in VEGF receptor-1 tyrosine kinase-deficient mice ( $\mathrm{TK}^{-/-}$mice). The mobilization of progenitor cells expressing VEGFR $1^{+}$cells from bone marrow and the recruitment of these cells to lung tissue were also suppressed in the $\mathrm{TK}^{-1-}$ mice. WT mice transplanted with bone marrow from $\mathrm{TK}^{-1}$ transgenic $\mathrm{GFP}^{+}$mice had significantly lower numbers of $\mathrm{GFP}^{+}$/aquaporin $5^{+}, \mathrm{GFP}^{+}$/surfactant protein $\mathrm{A}^{+}$, and $\mathrm{GFP}^{+} / \mathrm{VEGFR} 1^{+}$cells than WT mice transplanted with bone marrow from WTGFP ${ }^{+}$mice. The GFP ${ }^{+} / \mathrm{VEGFR} 1^{+}$cells also co-stained for aquaporin 5 and surfactant protein A. Overall, these results suggest that VEGF signaling contributes to compensatory lung growth by mobilizing VEGFR1 ${ }^{+}$cells.

Laboratory Investigation (2015) 95, 456-468; doi:10.1038/labinvest.2014.159; published online 2 February 2015

In adult ( 2 to 3 months old) mice, regeneration of lung tissue after pneumonectomy (PNX) occurs via growth of new and existing alveoli in the remaining lung lobes, leading to restoration of volume, surface area, ${ }^{1}$ alveolar number, and DNA and protein content within 14 days. $^{2}$ This phenomenon is termed compensatory lung growth, and PNX models have been used to evaluate postnatal lung growth because the remaining lung can be kept intact and volume loss can be controlled. ${ }^{3}$ It has recently been reported that bone marrow (BM)-derived cells play a crucial role in compensatory lung growth, ${ }^{4}$ and accumulating data suggest that these cells can serve as precursors for differentiated cells of multiple organs. ${ }^{5,6}$

Vascular endothelial growth factor (VEGF) is an endogenous proangiogenic factor that is important for the normal vascular development of numerous organ systems. ${ }^{7}$
The biological activity of VEGF is dependent on its interaction with specific receptors. Three VEGF tyrosine kinase (TK) receptors (VEGFRs) have been identified to date: VEGFR1, VEGFR2, and VEGFR3. VEGFR1 (FLT1) and VEGFR2 (FLK1) are expressed on endothelial cells and are linked to endothelial differentiation and vascular organization. ${ }^{8}$ During lung development, the vascular plexus sprouts in parallel with alveolar budding. In the pulmonary system, angiogenesis is of particular importance because the blood-air interface is the sole source of oxygen delivery to the body. VEGF is deposited in the subepithelial matrix at the leading edges of branching airways, where it stimulates angiogenesis. ${ }^{9}$

In the lung, alveolar type II cells (ATIIs) are the major source of VEGF; ; $10-12$ these epithelial cells secrete surfactant

\footnotetext{
${ }^{1}$ Department of Pharmacology, Kitasato University School of Medicine, Kanagawa, Japan; ${ }^{2}$ Department of Clinical Research Center, Kitasato University School of Medicine, Kanagawa, Japan; ${ }^{3}$ Department of Surgery, Kitasato University School of Medicine, Kanagawa, Japan; ${ }^{4}$ Department of Immunology, Kitasato University School of Medicine, Kanagawa, Japan; ${ }^{5}$ Department of Anatomy, Kitasato University School of Medicine, Kanagawa, Japan; ${ }^{6}$ Department of Thoracic Surgery, Kitasato University School of Medicine, Kanagawa, Japan and ${ }^{7}$ Department of Molecular Oncology, Tokyo Medical and Dental University, Tokyo, Japan

Correspondence: Professor M Majima, MD, PhD, Department of Pharmacology, Kitasato University School of Medicine, 1-15-1 Kitasato, Minami, Sagamihara, Kanagawa 252-0374, Japan.
}

E-mail: mmajima@med.kitasato-u.ac.jp

Received 28 January 2014; revised 31 October 2014; accepted 2 December 2014 
and maintain alveolar epithelial renewal. ${ }^{13}$ The production of VEGF by ATIIs is upregulated by hypoxia. ${ }^{14}$ ATIIs express both VEGFR1 and VEGFR2; VEGFR1 is expressed in the endothelium during vascular development at similar levels in embryos and adult mice. ${ }^{15}$ ATIIs are converted to alveolar type I cells (ATIs) during lung injury repair and fetal lung development; ${ }^{16}$ therefore, epithelial progenitors responsible for the repair and regeneration of damaged alveoli should be present within the same compartment as the ATIs. ${ }^{17}$ Transplantation of ATIIs derived from embryonic stem cells recently showed promise as an effective treatment for acute lung injury in adult mice. ${ }^{18}$

It has previously been reported that PNX stimulates pulmonary capillary endothelial cells to produce angiocrine factors that induce the proliferation of endothelial progenitor cells supporting alveologenesis; this process is mediated via a VEGFR2 and fibroblast growth factor receptor-1signalingdependent mechanism. Sinusoidal endothelial cells are an interconnected network of vessels encompassing the major BM vascular compartment that arise from cortical capillaries and interact with hematopoietic cells. ${ }^{19}$ A recent study in mice showed that VEGFR1 expression is elevated by day 3 after PNX, ${ }^{20}$ and additional studies showed that administration of soluble VEGFR1 prevents the binding of VEGF to its cognate cell surface receptors and suppresses compensatory lung growth and lung repair. ${ }^{21,22}$ These observations led to the hypothesis that VEGFR1 has a novel function beyond the role of lung alveolarization after PNX. Here, we examined the involvement of VEGFR1 TK signaling in compensatory lung growth using $\mathrm{TK}^{-1-}$ mice and wild-type (WT) mice.

\section{MATERIALS AND METHODS}

\section{Animals and Experimental Model}

Male C57BL/6 WT mice (7 to 8 weeks old) weighing 20-25 g were obtained from CLEA Japan (Tokyo, Japan). Male VEGFR1TK-knockout $\left(\mathrm{TK}^{-/-}\right)$mice (7 to 8 weeks old) weighing $20-25 \mathrm{~g}$ were generated as described previously. ${ }^{15}$ VEGF transgenic mice were established using a keratin 14 promoter expression cassette to target murine VEGF164 expression to basal epidermal keratinocytes and outer root sheath keratinocytes of hair follicles. The establishment and the phenotypic characterization of VEGF transgenic mice has been reported previously. ${ }^{13,23}$ All animals were maintained at constant humidity $(60 \pm 5 \%)$ and temperature $\left(20 \pm 1{ }^{\circ} \mathrm{C}\right)$ on a $12 \mathrm{~h} \mathrm{light/dark}$ cycle with food and water ad libitum. All animal experiments were approved by the Kitasato University School of Medicine (Kanagawa, Japan) and were performed in accordance with the Guidelines of Kitasato University School of Medicine for Animal and Recombinant DNA experiments.

Mice were anesthetized by intraperitoneal injection of ketamine $(5 \mathrm{mg} / \mathrm{kg}$ body weight $)$ and xylazine $(100 \mathrm{mg} / \mathrm{kg}$ body weight). The trachea was cannulated with a 23 -gauge atraumatic angiocatheter (BD Biosciences, Franklin Lakes, NJ, USA), and mechanical ventilation was achieved using a small animal ventilator. ${ }^{5,14}$ Left thoracotomy was performed at the fourth or fifth intercostal space through an anterior midaxillary incision. The hilum of the left lung was then ligated with 4-0-sized silk sutures and the lung was removed. The chest and skin were closed and mechanical ventilation was discontinued as spontaneous respiration was observed. The animals were then extubated. A group of mice of similar age and weight served as naive mice. The sham-operated mice underwent a simple left thoracotomy, but the left lung was neither ligated nor removed. The VEGF neutralizing antibody $(0.5 \mathrm{mg} / \mathrm{kg}$ body weight $)$ was injected intraperitoneally on a daily basis. ${ }^{24}$ The CXCR4 neutralizing antibody (10 $\mu \mathrm{g}$ per mouse, clone 2B11; BD Biosciences) was also injected intraperitoneally on a daily basis. ZD6474 (50 mg/kg; AstraZeneca, Cheshire, UK), a potent inhibitor of VEGFR2 TK activity, was administered orally as a suspension ( $0.1 \mathrm{ml}$ per $1.25 \mathrm{mg}$ of body mass) by oral gavage. ${ }^{25}$

\section{Lung Weight Measurement}

At the indicated time points after surgery, mice were weighed and anesthetized via intraperitoneal injection of pentobarbital sodium $(50 \mathrm{mg} / \mathrm{kg})$. Blood was drawn from a heart puncture and the mice were then exsanguinated. Subsequently, the remaining lungs were harvested and weighed, and the lung weights were divided by the body weight.

\section{Lung Volume Measurement}

After the right lung was excised, the lung was inflated with phosphate-buffered saline (PBS) at a pressure of $12 \mathrm{~cm} \mathrm{H}_{2} \mathrm{O}$. After $10 \mathrm{~min}$, the lung was tied off, and the fixed left lung volume was measured by the water displacement technique and divided to body weight. ${ }^{26}$

\section{Counting the Number of Alveoli}

The right lung was inflated with buffered zinc formalin at a pressure of $12 \mathrm{~cm} \mathrm{H}_{2} \mathrm{O}$. The tissue was fixed in a fresh fixative at $4{ }^{\circ} \mathrm{C}$ overnight and then imbedded in paraffin. The sections were cut and stained with hematoxylin and eosin. Digital images were captured using Olympus DP20 U-TV0.5XC-3 and DP2-BSW imaging software (Tokyo, Japan). The number of alveoli was counted by using image processing software (ImageJ, Wayne Rasband (NIH)). ${ }^{27}$

\section{Measurement of the Alveolar Area}

The lung was inflated by intratracheal instillation of $10 \%$ formalin with a constant hydrostatic pressure of $30 \mathrm{~cm} \mathrm{H}_{2} \mathrm{O}$. The trachea was then ligated and the lung was excised. The tissue was fixed in fresh fixative at $4{ }^{\circ} \mathrm{C}$ overnight and then imbedded in paraffin. The sections were cut and stained with hematoxylin and eosin. Digital images were captured using Olympus DP20 U-TV0.5XC-3 and DP2-BSW imaging software (Olympus, Tokyo, Japan). ImageJ processing software was used to calculate the alveolar area for each sample based on three random fields observed at a magnification of $\times 400$. Analysis of each section was carried out in a blinded 
manner. The total number of areas encountered in each field was counted and the mean value was calculated.

\section{Measurements of Plasma Levels of VEGF-A, SDF-1, proMMP-9, and SCF}

Plasma levels of VEGF-A, stromal-cell-derived-factor-1 (SDF-1), and stem cell factor (SCF), and BM levels of promatrix metalloproteinase-9 (pro-MMP-9) were assessed using specific ELISA kits (R\&D Systems, Minneapolis, MN, USA). These experiments were performed in duplicate.

\section{Measurement of Protein Level of VEGF in the Lung}

To assess VEGF levels, the lungs of $n=5-10$ mice were removed $0,7,14,21$, and 28 days following after PNX and homogenized in $1 \mathrm{ml}$ PBS, and murine VEGF was measured by ELISA and normalized to total protein levels. ${ }^{28}$

\section{Bone Marrow Chimeric Model of Green Fluorescent Protein}

BM transplantation was performed as described previously. ${ }^{29}$ Briefly, BM cells were obtained by flushing the cavities of freshly dissected femurs and tibias of donor male WT or $\mathrm{TK}^{-1-}$ /green fluorescent protein (GFP) transgenic mice (a gift from Dr M Okabe, Genome Information Research Center, Osaka University, Osaka, Japan) with PBS. The flushed BM cells were dispersed and then resuspended in PBS at a density of $1 \times 10^{7}$ cells $/ \mathrm{ml}$. WT mice were lethally irradiated with 10 Gy using an MBR-1505 R X-ray irradiator (Hitachi Medico, Tokyo, Japan) with a filter (copper, $0.5 \mathrm{~mm}$; aluminum, $2 \mathrm{~mm}$ ) and monitoring of the cumulative radiation dose. The BM mononuclear cells of GFP mice $\left(2 \times 10^{6}\right.$ cells in $200 \mu$ l of PBS $)$ were transplanted into irradiated WT mice via the tail vein. After 8 weeks, peripheral blood was collected and analyzed by fluorescenceactivated cell sorting. Mice in which $>90 \%$ of the peripheral leukocytes were GFP positive were used in the PNX experiment.

\section{Analysis of Recruitment of GFP-Positive Cells to Compensatory Lung Growth}

PNX was performed on WT mice transplanted with BM cells from WT transgenic $\mathrm{GFP}^{+}$mice and on $\mathrm{TK}^{-1-}$ transgenic $\mathrm{GFP}^{+}$mice (BM chimera). At the indicated time points after PNX, the GFP-BM transplantation chimeric mice were killed with an overdose of pentobarbital sodium and the lung tissues were carefully resected. ${ }^{30}$ The number of GFP- and $4^{\prime}, 6$ diamidino-2-phenylindole, dihydrochloride (DAPI)-positive cells was counted for each sample based on seven random fields observed at a magnification of $\times 400$. The percentage of $\mathrm{GFP}^{+}$cells was calculated by dividing the number of $\mathrm{GFP}^{+}$and $\mathrm{DAPI}^{+}$cells by the number of $\mathrm{GFP}^{+}$cells.

\section{Immunofluorescence Analysis}

Lung tissues were fixed with $4 \%$ paraformaldehyde in $0.1 \mathrm{M}$ phosphate buffer $(\mathrm{pH} 7.4)$ at $4{ }^{\circ} \mathrm{C}$ for $4 \mathrm{~h}$. After sequential cryoprotection in $0.1 \mathrm{M}$ phosphate buffers ( $\mathrm{pH}$ 7.2) containing 7.5, 15, and then $30 \%$ sucrose for $4 \mathrm{~h}$, cryostat sections of $\sim 8 \mu \mathrm{m}$ thickness were cut. The cryostat sections were blocked with $1 \%$ bovine serum albumin in PBS at room temperature for $1 \mathrm{~h}$ and then incubated at $4{ }^{\circ} \mathrm{C}$ overnight with anti-goat VEGFR1 antibody (1:200; Santa Cruz Biotechnology, Dallas, TX, USA), anti-rabbit aquaporin 5 (AQP) antibody (1:400; Abcam, Cambridge, UK), and anti-rabbit surfactant protein A (SPA) antibody (1:100; Santa Cruz Biotechnology). After three washes in PBS, the sections were incubated with a mixture of secondary antibodies for $1 \mathrm{~h}$ at room temperature. The secondary antibodies used were AlexaFluor 488-, 568-, or 647conjugated donkey anti-rabbit, anti-rat, or anti-goat IgGs (Molecular Probes, Eugene, OR, USA). Images were captured using a confocal scanning laser microscope (LSM710; Carl Zeiss, Jena, Germany).

\section{Flow Cytometric Analysis}

Blood was drawn via the tail vein on day 14 after surgery. The white blood cell fraction, including platelets, was obtained by Ficoll separation, and flow cytometric analysis was performed as described previously. ${ }^{31}$ The cells were labeled with FITClabeled anti-VEGFR1 in the presence of the anti-FcR monoclonal antibody 2.4G2 (BD Biosciences). After washing, the cells were analyzed with a FACSCalibur flow cytometer (BD Biosciences) and small cells (with low forward scatter) were gated for peripheral blood analysis. The white blood cell number was determined by counting the number of nucleated cells using a Celltac $\alpha$ hematology analyzer (MEK6450; Nihon Kohden, Tokyo, Japan). The percentage of VEGFR ${ }^{+}$cells was calculated based on the flow cytometry results. The number of VEGFR $1^{+}$cells was estimated by multiplying the flow cytometry results by the number of white blood cells.

\section{Determination of Expression Levels of the mRNAs Encoding VEGFR1-3 in Lung Tissue Following PNX}

Transcripts encoding VEGFR1-3 and GAPDH (as a control) were quantified by real-time RT-PCR analyses. The lungs were collected and homogenized with TRIzol reagent (GibcoBRL; Life Technologies, Rockville, MD, USA). The real-time PCR primers were designed using Primer 3 software (http:// primer3.sourceforge.net/) using the gene sequences deposited in GenBank. The following primers were used: $5^{\prime}$-GTCTC CATCAGTGGCTCTACG-3' (sense) and $5^{\prime}$-CCCGGTTCTT GTTGTATTTTG-3' (antisense) for VEGFR1; 5'-CTGCCTA CCTCACCTGTTTCC-3' (sense) and $5^{\prime}$-CGGCTCTTTCGC TTACTGTTC-3' (antisense) for VEGFR2; 5'-CAGCATCTA CTCGCGTCACAG-3' (sense) and 5'-AGACTACGCTGGGC AAACATC-3' (antisense) for VEGFR3; and 5'-CCCTTC ATTGACCTCAACTACAATGGT-3' (sense) and 5'-AAGGTG GAAGAGTGGGAGTTG-3' (antisense) for GAPDH (SigmaAldrich, Tokyo, Japan). 


\section{Statistical Analysis}

Data are expressed as the mean \pm s.d. Comparisons between two groups were performed using the Mann-Whitney $U$-test. Comparisons between the time points were analyzed using generalized estimating equations. $P<0.05$ was considered statistically significant.

\section{RESULTS \\ VEGF Promotes Compensatory Lung Growth}

After PNX of the left lung of male C57BL/6 WT mice, dramatic regeneration occurred in the remaining right lung (Figure 1a). At days 1-28 after surgery, the right lung to body weight ratio was significantly higher in the PNX group than in the sham-operated group (Figure 1b); at day 14 , the mean ratio in the PNX group was $5.99 \pm 0.17 \mathrm{mg} / \mathrm{g}$ and the mean ratio in the sham-operated group was $3.99 \pm 0.05 \mathrm{mg} / \mathrm{g}(P<0.05)$. Furthermore, the lung volume to body weight was also significantly higher in the PNX group than in the sham-operated group (PNX, $0.051 \pm 0.007 \mathrm{ml} / \mathrm{g}$; sham operation; $0.026 \pm 0.0046 \mathrm{ml} / \mathrm{g} ;{ }^{\star} P<0.05$; Figure 1c) and the dry lung weight (Supplementary Figure S1). However, there were no significant differences in the alveoli areas $(P=0.67$; Figure $1 \mathrm{~d})$ and the number of alveoli $(P=0.12$; Figure $1 \mathrm{e})$.

VEGF is an important factor for blood formation during lung growth and repair. ${ }^{89}$ To determine whether VEGF signaling is involved in compensatory lung growth following PNX, the plasma level of VEGF was examined in shamoperated mice and mice undergoing PNX. The level of VEGF in the plasma was significantly higher in the PNX group than the sham-operated group (PNX, $114.8 \pm 21.46 \mathrm{ng} / \mathrm{ml}$; sham, $63.1 \pm 18.94 \mathrm{ng} / \mathrm{ml} ; P<0.05$; Figure 1f). Moreover, the protein level of VEGF in the lung was significantly increased compared with sham-operated mice on day 7 (PNX, $23.4 \pm 3.99 \mathrm{pg} / \mathrm{mg}$ protein; Sham, $13.3 \pm 3.17 \mathrm{pg} / \mathrm{mg}$ protein; ${ }^{\star} P<0.05$; Figure 1e).

Next, the right lung weights after left PNX were examined in WT mice and transgenic mice overexpressing VEGF-A. There was no difference in lung weight between VEGF transgenic mice and Balb/c mice (Balb/c: $4.13 \pm 0.09 \mathrm{mg} / \mathrm{g}$, VEGF transgenic mice: $4.29 \pm 0.4 \mathrm{mg} / \mathrm{g} ; P=0.412)$. However, the right wet lung weight (ATG, $6.10 \pm 0.23 \mathrm{mg} / \mathrm{g}$; Balb/c, $5.85 \pm 0.16 \mathrm{mg} / \mathrm{g} ;{ }^{\star} P<0.05$; Figure $2 \mathrm{a}$ ) and dry lung weight (Supplementary Figure S2A) were significantly increased compared with that in the Balb/c mice on day 14 following PNX. To confirm that VEGF plays a role in lung growth, mice were treated with a neutralizing antibody against VEGF. Compared with IgG-injected control mice, compensatory lung growth after PNX was suppressed significantly by injecting the mice with a VEGF neutralizing antibody (VEGF neutralizing antibody, $5.06 \pm 0.38 \mathrm{mg} / \mathrm{g}$; IgG, $6.09 \pm 0.64 \mathrm{mg} /$ g; $P<0.05$; Figure 2b). As shown in Supplementary Figure S2B, the dry wet right lung weight in mice treated with VEGF neutralized antibody was reduced at days 7 and 14 .

\section{VGFR1 Is Involved in Contralateral Compensatory Lung Growth}

VEGF interacts with VEGFR1, VEGFR2, and VEGFR3, all of which are located on the plasma membrane. VEGFR1 and VEGFR2 are involved in the enhancement of angiogenesis. ${ }^{9}$ To determine which of the three VEGFR subtypes contribute to compensatory lung growth, the expression levels of the mRNAs encoding them were measured in the right lung using real-time RT-PCR. Expression of the mRNA encoding VEGFR1 was enhanced significantly after PNX (Figure 2c), but the expression levels of the mRNAs encoding VEGFR2 and VEGFR3 were not affected by the surgery (Figure $2 \mathrm{~d}$ and e). Furthermore, treatment of mice with ZD6474, a VEGFR2 TK inhibitor, had no effect on the right lung to body weight ratio in mice undergoing left PNX (vehicle, $5.92 \pm 0.62 \mathrm{mg} / \mathrm{g}$; ZD6474, $5.95 \pm 0.63 \mathrm{mg} / \mathrm{g} ; P=0.954$; Figure $2 \mathrm{f}$ and Supplementary Figure $\mathrm{S} 2 \mathrm{C})$. In contrast, the wet right lung weight $\left(\mathrm{TK}^{-1-}\right.$, $5.55 \pm 0.34 \mathrm{mg} / \mathrm{g}$; WT, $6.05 \pm 0.12 \mathrm{mg} / \mathrm{g} ; P<0.05$; Figure $2 \mathrm{~g}$ ). We also determined dry lung weight of the lung. The result indicated that dry weight of the residual right lung following left PNX was significantly reduced in $\mathrm{TK}^{-1-}$ mice (Supplementary Figure S2D) but not in ZD6474-treated mice (Supplementary Figure S2C) when compared with respective control.

To further elucidate the role of VEGFR1 signaling in compensatory lung growth following after PNX, we determined the lung volume and the number of alveoli in $\mathrm{TK}^{-1-}$ mice. As shown in Figure 3a, there was no significant difference in the remaining right lung volumes following PNX of the left lung $\left(\mathrm{TK}^{-l-}, \quad 0.047 \pm 0.004 \mathrm{ml} / \mathrm{g} ; \quad W T 0.046 \pm 0.003 \mathrm{ml} / \mathrm{g}\right.$; $\left.{ }^{\star} P=0.54\right)$ between $\mathrm{TK}^{-1-}$ mice and WT. However, the number of alveoli in $\mathrm{TK}^{-1-}$ mice were smaller than those in WT mice (day 7, $\mathrm{TK}^{-1-}, 8.75 \pm 0.12 / 10^{4} \mu \mathrm{m}^{2}$; WT, $12.2 \pm 1.1 / 10^{4} \mu \mathrm{m}^{2}$; day $14, \mathrm{TK}^{-1-}, 9.35 \pm 1.04 / 10^{4} \mu \mathrm{m}^{2}$; WT, $11.6 \pm 1.12 / 10^{4} \mu \mathrm{m}^{2} ;{ }^{\star} P<0.05$; Figure $\left.3 \mathrm{~b}\right)$. We also measured the protein levels of VEGF in the lung, which is ligand of VEGFR1. As demonstrated in Figure 3c, pulmonary levels of VEGF in $\mathrm{TK}^{-1-}$ mice with PNX were significantly suppressed as compared with WT mice at days 7 and 14 (7 days, $\mathrm{TK}^{-1-}, 5.55 \pm 0.34 \times 10^{-3} \mathrm{~g} / \mathrm{g}$; WT, $6.05 \pm 0.12 \times 10^{-3} \mathrm{~g} / \mathrm{g}$; 14 days, $\mathrm{TK}^{-1-}, \quad 5.55 \pm 0.34 \times 10^{-3} \mathrm{~g} / \mathrm{g} ; \quad \mathrm{WT}, \quad 6.05 \pm$ $0.12 \times 10^{-3} \mathrm{~g} / \mathrm{g} ;{ }^{\star} P<0.05$; Figure $\left.3 \mathrm{c}\right)$.

\section{Hematopoietic Cytokine Levels Are Reduced Following Knockout of VEGFR1}

VEGF-A and SDF-1, the other hematopoietic growth factors (including SCF through MMP-9), are responsible for mobilization of BM-derived VEGFR1 ${ }^{+}$cells relevant to angiogenesis $^{32}$ As the level of VEGF in the plasma was higher in the PNX group than the sham-operated group, the level of VEGF in the plasma was also determined in the VEGFR1 $\mathrm{TK}^{-1-}$ and WT mice. At day 7 after PNX, the plasma levels of VEGF-A were comparable in $\mathrm{WT}$ and $\mathrm{TK}^{-1-}$ mice (WT, $82.9 \pm 10.89 \mathrm{ng} / \mathrm{ml}$ TK ${ }^{-1-}, 86.7 \pm 13.24 \mathrm{ng} / \mathrm{ml}$; 


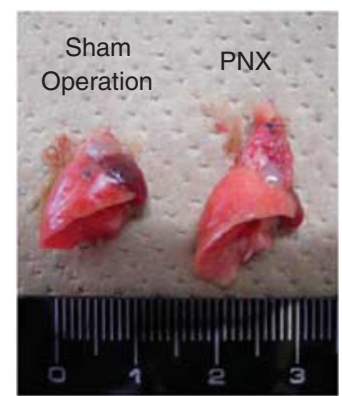

b

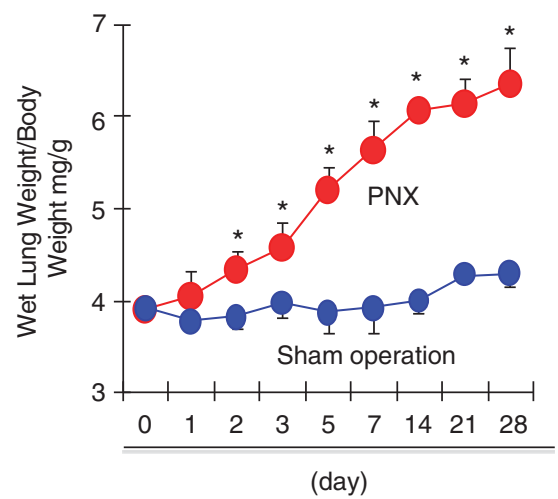

C

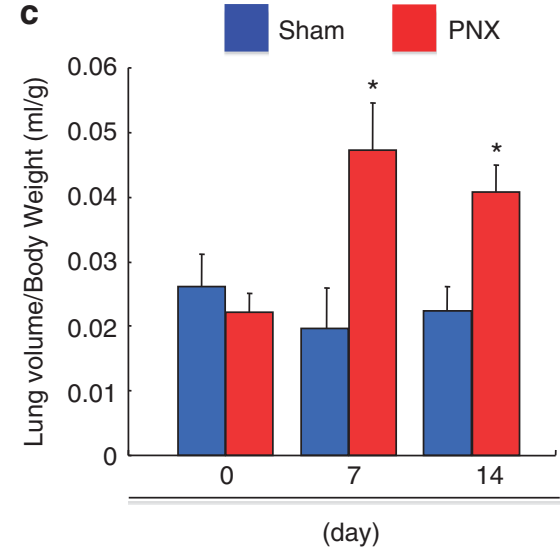

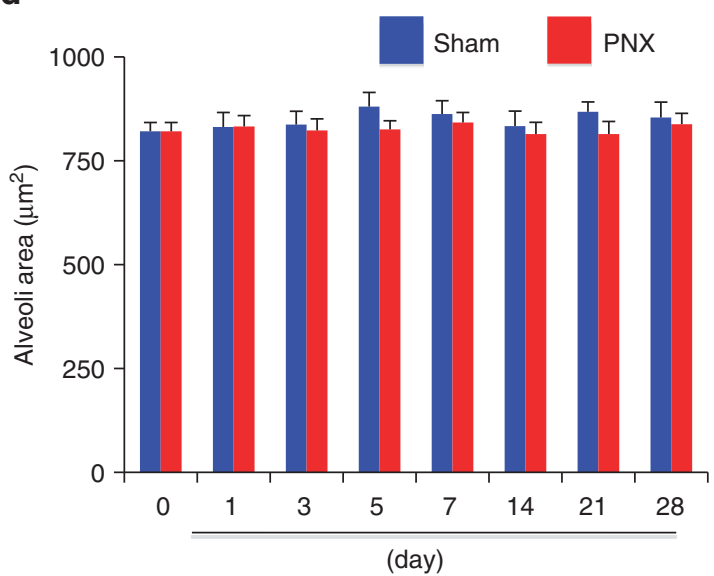

f

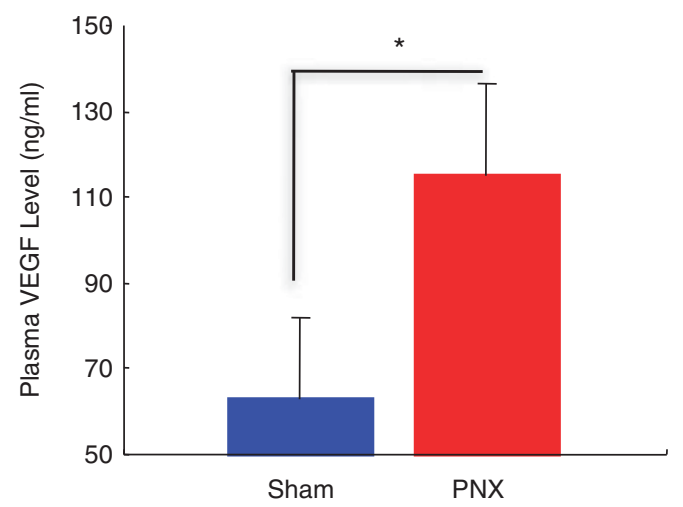

e

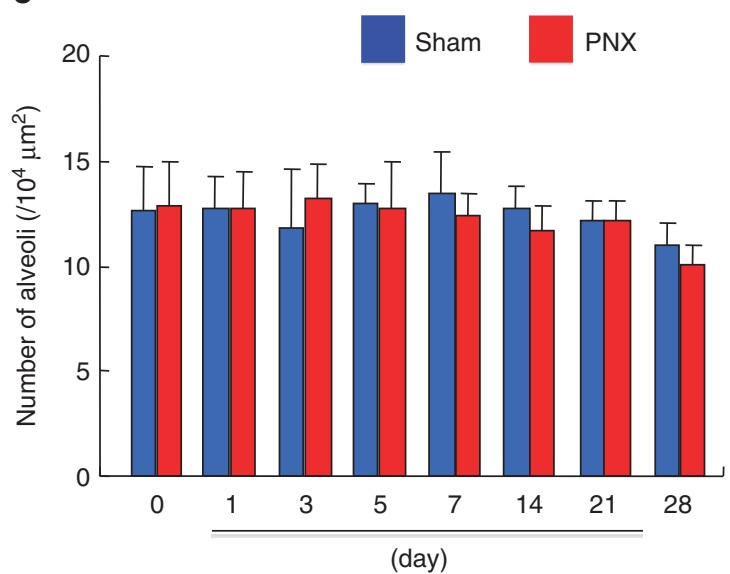

g

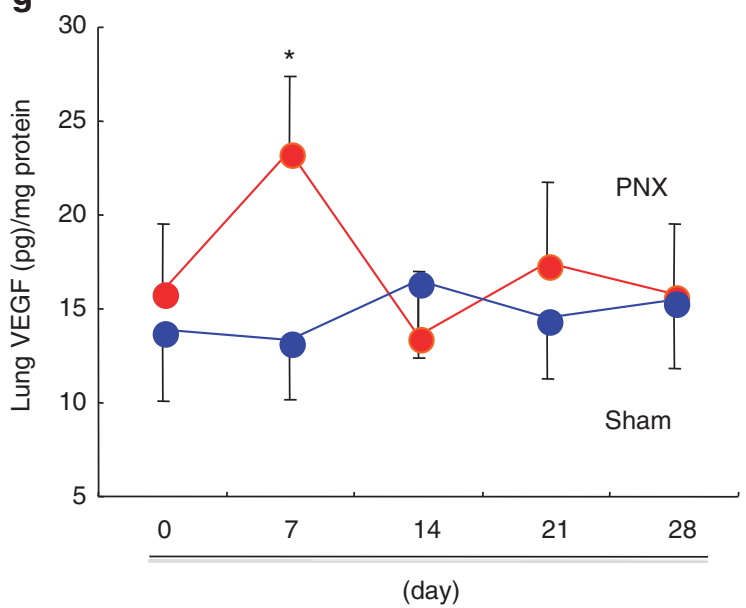

Figure 1 VEGF induces compensatory lung growth following PNX. (a) Right lungs from representative animals in the PNX and sham-operated groups. $(\mathbf{b}, \mathbf{c}, \mathbf{d}, \mathbf{e})$ The right lung to body weight ratios (b), lung volume (c), alveolar areas (d), and number of alveoli (e) in the PNX and sham-operated groups at the indicated time points after surgery. Data are represented as the mean \pm s.d. of $n=6-10$ mice. ${ }^{*} P<0.05$ versus sham operated by Student's $t$-tests. (f) The plasma VEGF level in the PNX and sham-operated groups at day 7after surgery. Data are represented as the mean $\pm s$.d. of $n=6$ mice. ${ }^{*} P<0.05$ by Student's $t$-test. (g)The protein level of VEGF in the lung was increased following PNX. The PNX group, pneumonectomy; the sham group, sham operation. Data are means \pm s.d. for the number of mice $(n=6-8) .{ }^{*} P<0.05$ versus sham operated by Student's $t$-tests.

$P>0.54$; Figure 4a). Conversely, the plasma level of SDF-1, a chemokine in $\mathrm{BM}$ that mediates its effects by binding to C-XC chemokine receptor type 4 (CXCR4), was significantly lower in $\mathrm{TK}^{-1-}$ mice than WT mice (WT, $16.4 \pm 5.35 \mathrm{ng} / \mathrm{ml}$; $\mathrm{TK}^{-I-}, 6.06 \pm 2.56 \mathrm{ng} / \mathrm{ml} ; P<0.05$; Figure $4 \mathrm{~b}$ ). The levels of the hematopoietic cytokines pro-MMP-9 and SCF were also 
a

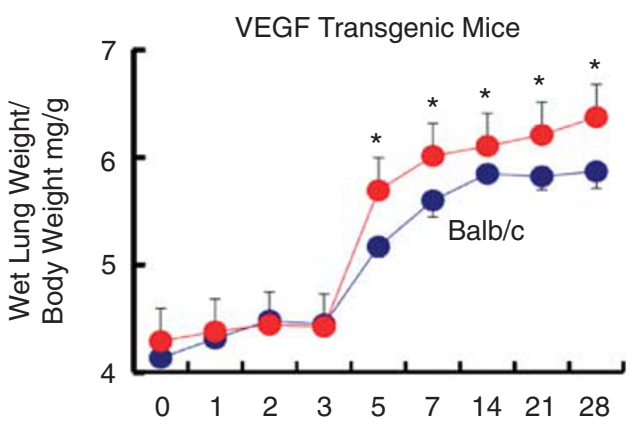

(day)

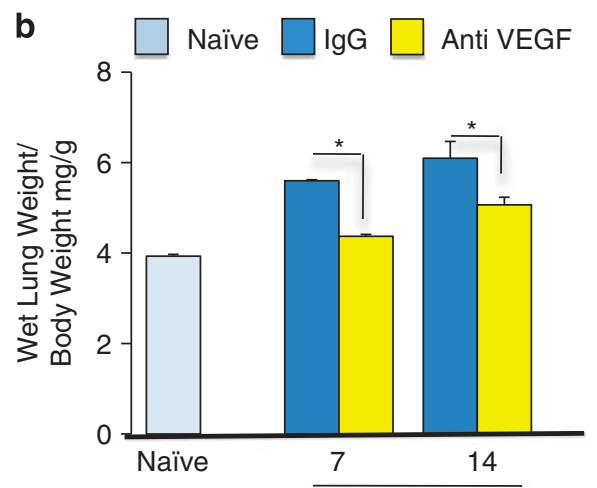

(day)

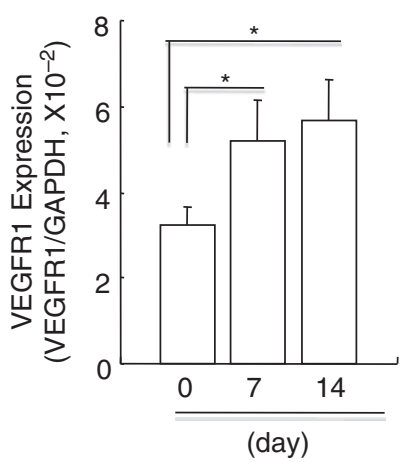

f

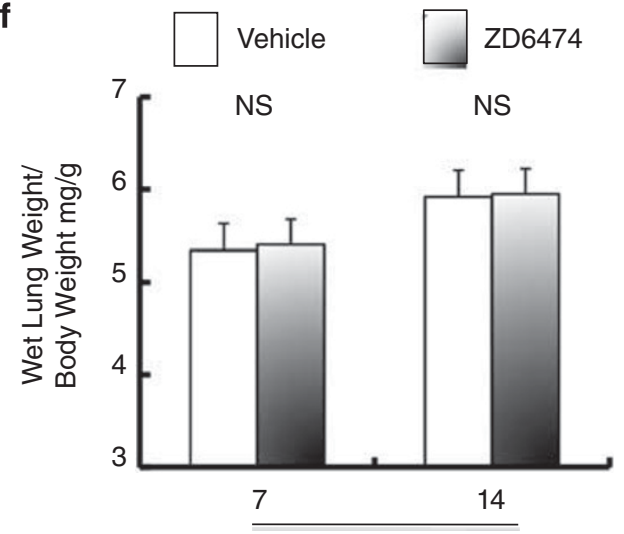

(day) d

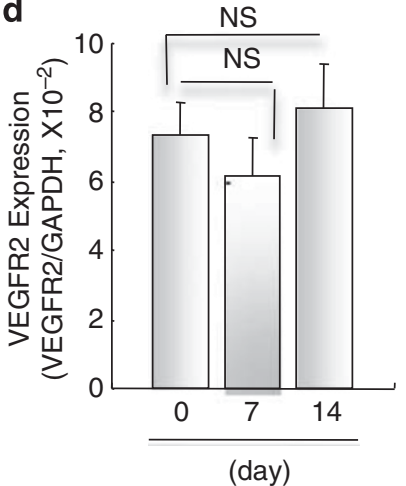

e

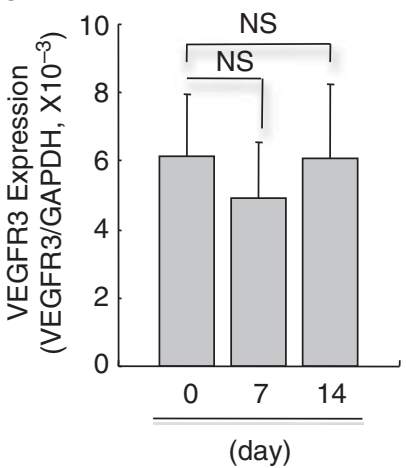

g

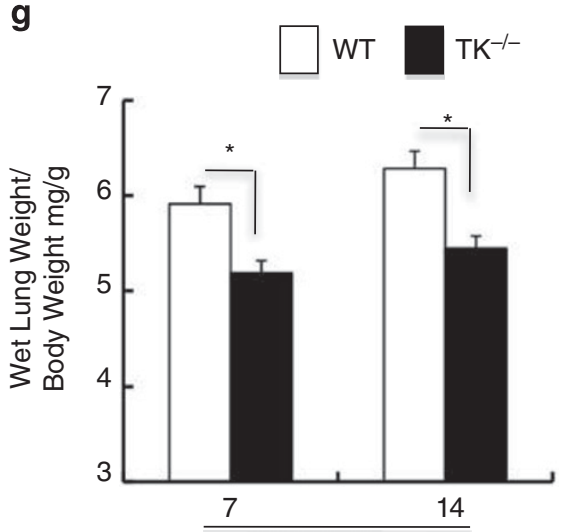

(day)

Figure 2 VEGFR1 TK signaling is involved in compensatory lung growth following PNX. (a)The wet right lung to body weight ratios at the indicated time points after PNX in WT (Balb/c) and VEGF-A transgenic mice. Data are represented as the mean \pm s.d. of $n=6$ mice. ${ }^{*} P<0.05$ versus WT mice by Student's $t$-tests. (b) The effect of injection of mice with a VEGF neutralizing antibody or IgG (control) on the wet right lung to body weight ratios on days 7 and 14 after PNX. Data are represented as the mean \pm s.d. of $n=6$ mice. ${ }^{*} P<0.05$ by Student's $t$-test. (c-e) Real time RT-PCR analyses of the expression levels of the mRNAs encoding VEGFR1, VEGFR2, and VEGFR3 in the lung following PNX. Expression levels were normalized to those of the mRNA encoding GAPDH. Data are represented as the mean \pm s.d. of $n=6$ mice. NS, not significant (by Student's $t$-test). (f) The wet right lung to body weight ratios at the indicated time points after left PNX in mice injected with the VEGFR2 inhibitor ZD6274 or lgG as a control. Data are represented as the mean \pm s.d. of $n=6$ mice. NS, not significant. (g) The wet right lung to body weight ratios at the indicated time points after left PNX in WT and VEGFR1 $\mathrm{TK}^{-/-}$mice. Data are represented as the mean \pm s.d. of $n=5$ mice. ${ }^{*} P<0.05$ by Student's $t$-tests.

measured. At day 7 after PNX, the BM levels of pro-MMP9 and plasma levels of SCF in $\mathrm{TK}^{-1}-$ mice $(2042 \pm 134.6 \mathrm{ng} / \mathrm{ml}$ and $74.1 \pm 21.3 \mathrm{pg} / \mathrm{ml}$, respectively) were significantly lower than those in WT mice $(9315 \pm 680 \mathrm{ng} / \mathrm{ml}$ and $152.3 \pm 29.7 \mathrm{pg} /$ $\mathrm{ml}$, respectively; $P<0.05$; Figure $4 \mathrm{c}$ and $\mathrm{d}$ ).

\section{Mobilization of VEGFR1 ${ }^{+}$Hematopoietic Cells to the Remaining Lung Is Impaired in VEGFR1 TK $^{-/}$Mice} An increase in hematopoietic cytokine levels mobilizes hematopoietic progenitor cells to promote tumor growth, and VEGFR $1^{+}$hematopoietic progenitors are required for the 

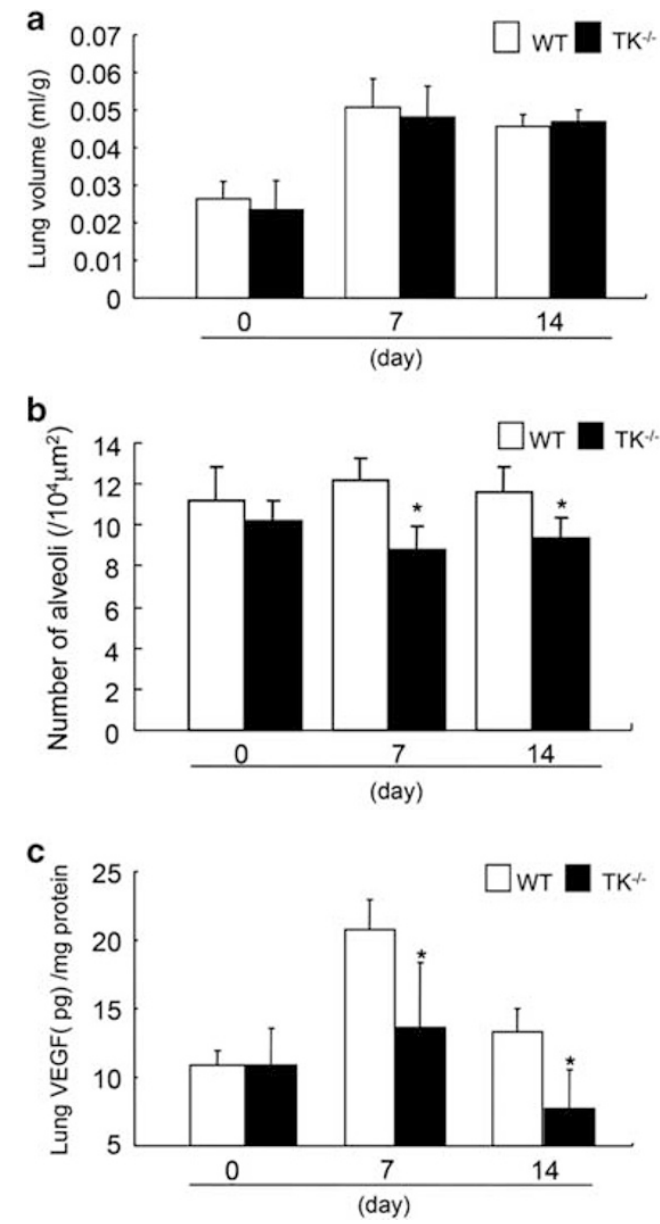

Figure 3 The effect of VEGFR1 TK signaling on lung volume and VEGF concentration in the lung following PNX. (a) There is no difference in the lung volume between $\mathrm{TK}^{-1-}$ mice following PNX. Data are means \pm s.d. for the number of mice $(n=6)$. NS, not significant by Student's $t$-tests. (b) The number of alveoli was diminished PNX. Data are means \pm s.d. for the number of mice $(n=6-10) .{ }^{*} P<0.05$ by Student's $t$-tests. (c) The protein level of VEGF in the lung was suppressed in $\mathrm{TK}^{-1-}$ mice following PNX. TK ${ }^{-1-}$, tyrosine kinase knockout. Data are means \pm s.d. for the number of mice $(n=6) .{ }^{*} P<0.05$ by Student's $t$-tests.

regulation of tumor metastasis. ${ }^{33}$ We reported previously that mobilization of VEGFR $1^{+} / \mathrm{CXCR} 4^{+}$hemangiocytes to ischemic limbs is important for recovery from ischemia and metastasis formation. ${ }^{30,34}$ Therefore, WT and VEGFR1 $\mathrm{TK}^{-1-}$ mice were used to determine whether the mobilization and recruitment of VEGFR $1^{+} / \mathrm{CXCR} 4^{+}$cells to the right lung after left PNX is dependent on VEGFR1 TK signaling. Compensatory lung growth was suppressed by injection of the mice with a VEGF neutralizing antibody, and then VEGFR $1^{+}$and $\mathrm{CXCR} 4^{+}$cells were quantified using flow cytometry. At days 7 and 14 after surgery, the total number and percentage of VEGFR $1^{+}$cells in peripheral blood were significantly lower in $\mathrm{TK}^{-1-}$ mice than WT mice (Figure $4 \mathrm{e}$ and Supplementary Figure S3A). On day 14, the percentages of VEGFR $1^{+}$cells in the WT and $\mathrm{TK}^{-1-}$ mice were $1.69 \pm 0.88$ and $0.92 \pm 0.34 \%$, respectively $(P<0.05$;
Figure 4e), and the total numbers of VEGFR $1^{+}$cells in these groups were $136.5 \pm 36.67$ and $75.1 \pm 13.83$, respectively $(P<0.05)$. However, there were no significant differences between the total numbers of $\mathrm{CXCR}^{+}$or $\mathrm{VEGFR}^{+}$, $\mathrm{CXCR}^{+}$cells in the peripheral blood of $\mathrm{WT}$ and $\mathrm{TK}^{-1-}$ mice (Supplementary Figure S3B and C).

If SDF-1 is essential for compensatory lung growth, the weight of the remaining right lung after left PNX should be suppressed by treatment with a CXCR4 neutralizing antibody. However, there were no significant differences between the mean right lung to body weight ratios in CXCR4 antibody-treated and IgG-treated mice at days 7 and 14 after PNX (Supplementary Figure S4A and B). These results suggest that compensatory lung growth in mice is not dependent on SDF-1/CXCR4 signaling. The accumulation of VEGFR $1^{+}$cells in lung tissues was then determined by immunostaining on day 14 after PNX (Figure 4f). VEGFR1 ${ }^{+}$ cells were located in the alveolar wall spaces in the WT mice but were rarely detected in the $\mathrm{TK}^{-1-}$ mice. However, there was no difference in the expression of VEGFR2 in the lung between WT and $\mathrm{TK}^{-l-}$ mice (Supplementary Figure S5).

Transplantation of BM Cells from VEGFR1TK ${ }^{-1-}$ Mice into WT Mice Attenuates Compensatory Lung Growth

Lung stem cells are capable of creating bronchioles, alveoli, and pulmonary vessels. ${ }^{35,36}$ To determine whether BM stem cells contribute to compensatory lung growth, BM cells from WT or VEGFR1TK ${ }^{-1-}$ transgenic $\mathrm{GFP}^{+}$mice were transplanted into WT mice 60 days before PNX. At days 7 and 14 after PNX, the percentage of $\mathrm{GFP}^{+}$cells in the lung was significantly lower in mice that were transplanted with the $\mathrm{TK}^{-1-} \mathrm{GFP}^{+} \mathrm{BM}$ than those that were transplanted with the $\mathrm{WT} \mathrm{GFP}^{+} \mathrm{BM}$ (day 14: $\mathrm{TK}^{-1-} \mathrm{GFP}^{+} \mathrm{BM}$, $21.80 \pm 6.34 \%$; WTGFP $^{+}$BM, $37.95 \pm 7.82 \% ; \quad P<0.05$; Figure $5 \mathrm{a}$ and $\mathrm{b})$. The alveolar areas in these two groups were comparable (Figure $5 \mathrm{c}$ ), but the relative weight of the right lung at day 14 after PNX was significantly lower in the $\mathrm{TK}^{-1-} \mathrm{GFP}^{+}$BM-transplanted mice than the WT $\mathrm{GFP}^{+}$ BM-transplanted mice (WT GFP ${ }^{+} \mathrm{BM}, 5.43 \pm 0.25 \mathrm{mg} / \mathrm{g}$; $\mathrm{TK}^{-l-} \mathrm{GFP}^{+} \mathrm{BM}, 4.69 \pm 0.14 \mathrm{mg} / \mathrm{g} ; P<0.05$; Figure $5 \mathrm{~d}$ ). Furthermore, there were no differences between the lung vascular densities in the two groups (Figure 5e).

\section{Recruitment of BM Cells Expressing VEGFR1 Contributes to Compensatory Lung Growth by Increasing the Numbers of ATIls}

Respiratory gas exchange is mediated by the alveolar epithelium, mainly via the action of ATIs and ATIIs. Within the alveolus, ATIIs act as facultative progenitor cells and are capable of replacing themselves as well as differentiating into ATIs after injury. ${ }^{20}$ Human recombinant VEGF induces ATII proliferation and stimulates the expression of surfactant protein; ${ }^{37}$ therefore, the effects of PNX and knockout of VEGFR1 on the numbers of ATIs and ATIIs were examined in mice. In WT mice, the pneumocyte-like cells, especially ATIIs, 

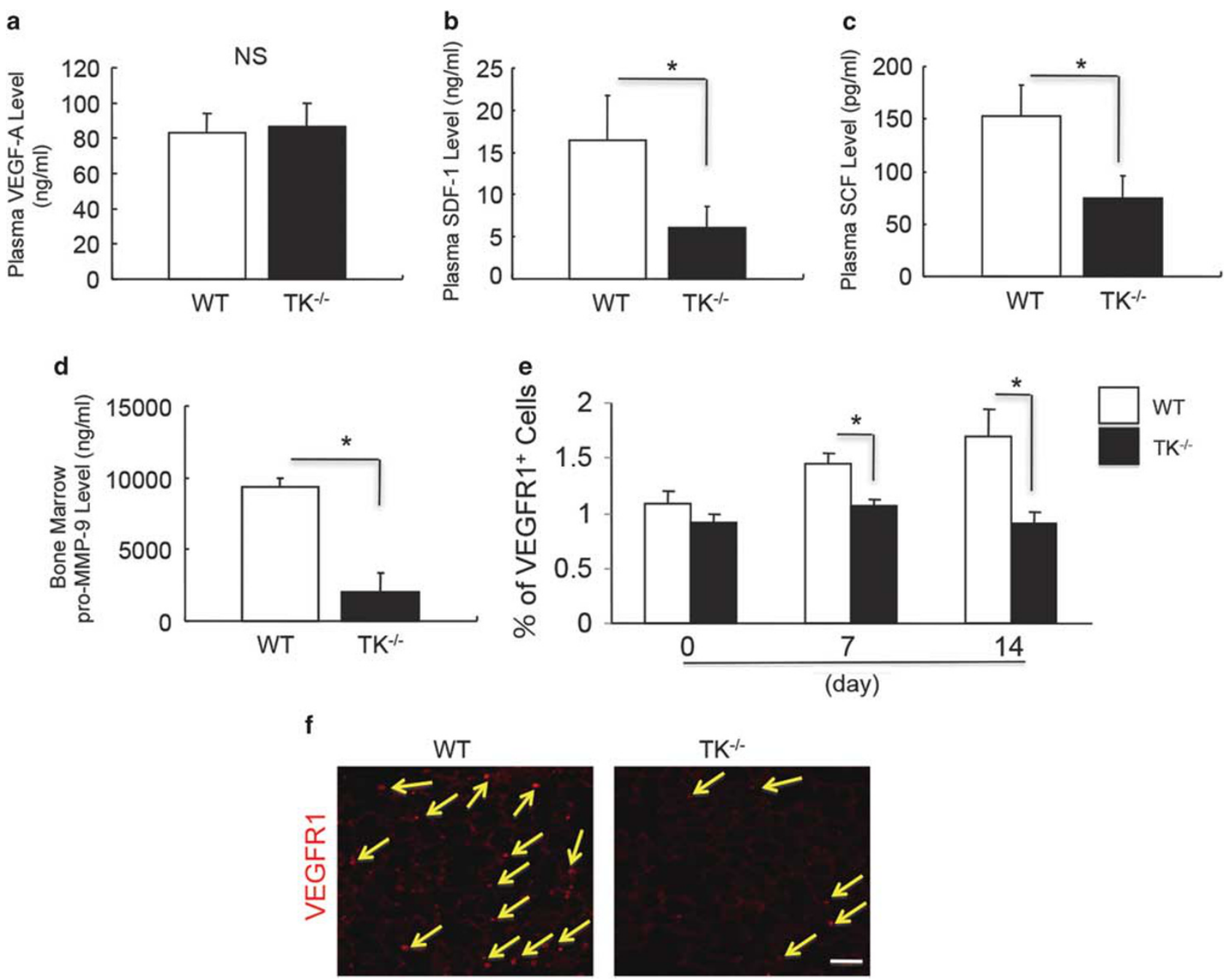

Figure 4 Hematopoietic cytokine levels and the mobilization of VEGFR1 ${ }^{+}$cells to the lung after PNX are reduced following knockout of VEGFR1. (a, b) Plasma levels of VEGF-A (a) and SDF-1 (b) on day 7 after PNX in WT and VEGFR1 TK ${ }^{-1-}$ mice. Data are represented as the mean \pm s.d. of $n=6$ mice. ${ }^{*} P<0.05$ by Student's $t$-test. NS, not significant by Student's $t$-test. (c, d) BM levels of pro-MMP-9 (c) and plasma levels of SCF (d) on day 7 after PNX in WT and VEGFR1 TK ${ }^{-1-}$ mice. Data are represented as the mean \pm s.d. of $n=8$ mice. ${ }^{*} P<0.05$ by Student's $t$-tests. (e) The percentages of VEGFR $1^{+}$cells in peripheral blood on days 0,7 , and 14 after PNX in WT and VEGFR1 TK ${ }^{-1}$ mice. Data are represented as the mean \pm s.d. of $n=10$ mice. ${ }^{*} P<0.05$ by Student's $t$-tests. (f) Immunostaining of VEGFR1 ${ }^{+}$cells in the lungs of WT and VEGFR1 TK ${ }^{-\prime-}$ mice at day 14 after PNX. The arrows indicate VEGFR1 ${ }^{+}$cells. Scale bar $=50 \mu \mathrm{m}$.

migrated into the alveolar septum on day 7 after PNX; however, this migration did not occur in $\mathrm{TK}^{-1-}$ mice (Supplementary Figure S6). To determine whether BM-derived cells from WT or VEGFR1 $\mathrm{TK}^{-1-}$ transgenic $\mathrm{GFP}^{+}$ mice are capable of migrating into the lung, we performed immunofluorescent analyses of AQP and SPA in WT BMtransplanted mice, as markers for ATIs and ATIIs, respectively. Co-staining of lung sections with antibodies for SPA and GFP or AQP and GFP revealed that, at 14 days after PNX, the $\mathrm{TK}^{-1-} \mathrm{GFP}^{+} \mathrm{BM}$-transplanted mice had markedly lower levels of VEGFR $1^{+} / \mathrm{GFP}^{+}, \mathrm{SPA}^{+} / \mathrm{GFP}^{+}$, and $\mathrm{AQA}^{+} /$ $\mathrm{GFP}^{+}$cells in the lung than the $\mathrm{WT} \mathrm{GFP}^{+}$BM-transplanted mice (Figure 6a). Furthermore, immunohistochemical staining of lung sections revealed that, at days 7 and 14 after
PNX, the numbers of $\mathrm{SPA}^{+} / \mathrm{VEGFR} 1^{+} / \mathrm{GFP}^{+}$and $\mathrm{AQP}^{+} /$ VEGFR $1^{+} / \mathrm{GFP}^{+}$cells in $\mathrm{TK}^{-1-} \mathrm{GFP}^{+}$BM-transplanted mice were lower than those in $\mathrm{WT} \mathrm{GFP}^{+}$BM-transplanted mice (Figure 6b-d).

\section{DISCUSSION}

The objective of this study was to investigate the role of VEGFR1 TK signaling in compensatory lung growth. The results indicate that endogenous VEGFR1 TK signaling promotes compensatory lung growth by remobilizing VEGFR $1^{+}$BM-derived proangiogenic cells in the lung. The BM-derived VEGFR $1^{+}$cells examined also expressed SPA and AQP, markers for ATIIs and ATIs, respectively. 
a

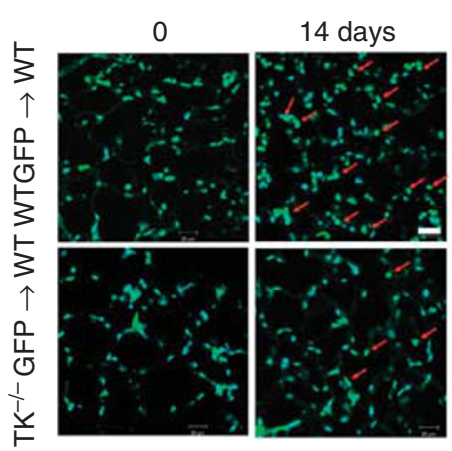

d

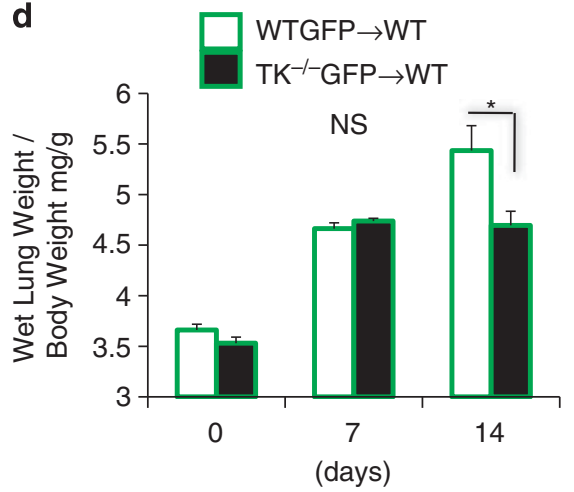

b

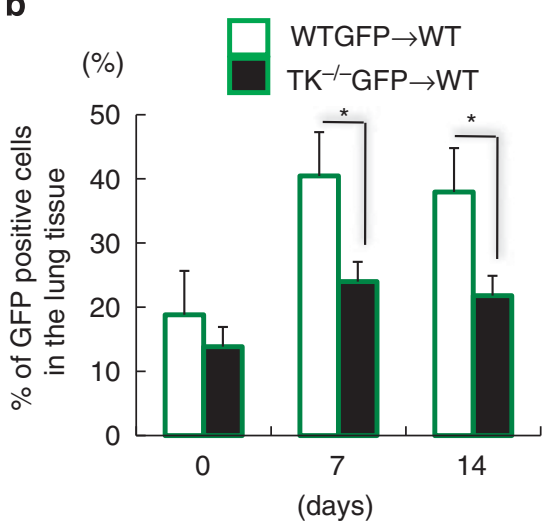

e

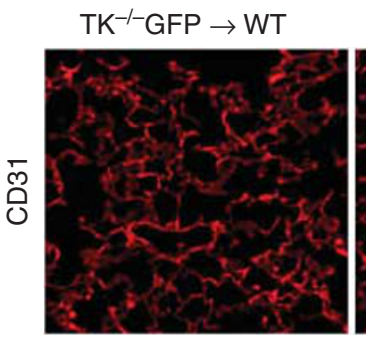

C

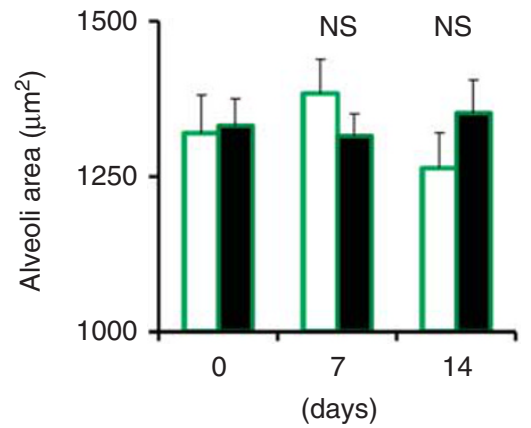

WTGFP $\rightarrow$ WT

WTGFP $\rightarrow W T$

(days)

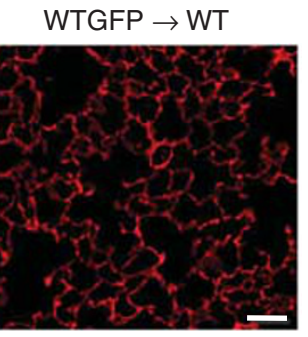

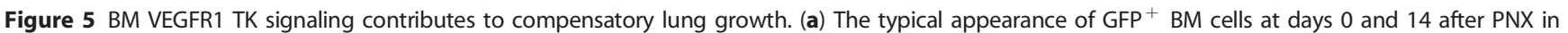
lungs from WT mice transplanted with BM cells from WT or VEGFR1 TK ${ }^{-1-}$ transgenic GFP ${ }^{+}$mice. The arrows indicate GFP ${ }^{+} \mathrm{DAPI}^{+}$double-positive cells. Scale bar $=20 \mu \mathrm{m}$. (b-d) The percentages of GFP ${ }^{+}$BM cells (b), alveolar areas (c), and relative lung weights (d) at days 0,7 , and 14 after PNX in lungs from BM transplanted mice. Data are represented as the mean \pm s.d. of $n=6(\mathbf{b}), n=20$ (c), or $n=5$ (d) mice. ${ }^{*} P<0.05$ by Student's $t$-tests. NS, not significant by Student's $t$-tests. (e) Immunofluorescent analysis of CD31 expression at day 14 after PNX in lungs from BM transplanted mice. Scale bar $=50 \mu \mathrm{m}$.

The experimental PNX model is a robust model for characterizing the mechanisms involved in and the limits of adaptation to the loss of lung units. ${ }^{10,38}$ The degree of compensatory lung growth differs among species and varies with age. Small animals such as rodents have a better capacity for compensatory lung growth than large animals. ${ }^{39}$ Increased lung mass following PNX is due to induction of cell proliferation in the residual lung tissue rather than hypertrophy of the remaining cell populations. Here, compensatory lung growth occurred at days 7 and 14 after PNX.

In young adult (7-8 weeks of age) mice, regeneration after PNX occurs through growth of existing alveoli in the remaining lung lobes. It may be plausible that lungs from young-aged mice have a better capacity for acceleration of lung growth than lungs from old-aged mice, and the regenerative capacity of the murine lung is progressively lost with age. Therefore, in the present experimental conditions, PNX in young adult mice induces accelerated growth of remaining existing lungs, indicating compensatory lung growth, but not de novo lung regeneration.

Maturational lung growth is controlled by a variety of growth factors. ${ }^{40}$ VEGF is an important factor in the normal vascular development of numerous organ systems. ${ }^{41}$ VEGF is expressed at high levels in the airway and alveolar septum, placing it in a position to mediate airway-vascular interactions. ${ }^{9,37}$ Heterozygous VEGF $^{-1-}$ mice die at the embryonic stage $^{41}$ and postnatal inactivation of VEGF increases mortality. ${ }^{42}$ VEGF is induced by hypoxia and stretch, and its expression is also modulated by a number of other growth factors. ${ }^{7,8}$, The major isoforms of VEGF (VEGF-120, VEGF-164, and VEGF-188) act through two TK receptors that are localized mainly to endothelial cells. VEGFR1 is primarily responsible for endothelial cell maintenance and vascular organization, ${ }^{43}$ whereas VEGFR2 regulates endothelial cell differentiation and migration, vascular permeability, ${ }^{44}$ and lung maturation. ${ }^{45}$ VEGF is also an important factor for the growth of neovascular alveolar cells. $^{10,46}$ Airway epithelial cells express VEGF and its receptors, ${ }^{46}$ and VEGF stimulates alveolar epithelial cell proliferation as well as surfactant production in vitro. ${ }^{47}$ In adult rats, chronic VEGFR blockade results in not only pulmonary arterial pruning, but also apoptosis of alveolar septal cells, resulting in an emphysema-like morphology. ${ }^{48}$

Here, VEGF transgenic mice displayed a significantly higher degree of compensatory lung growth than control mice, and this lung development was suppressed by injecting 
a

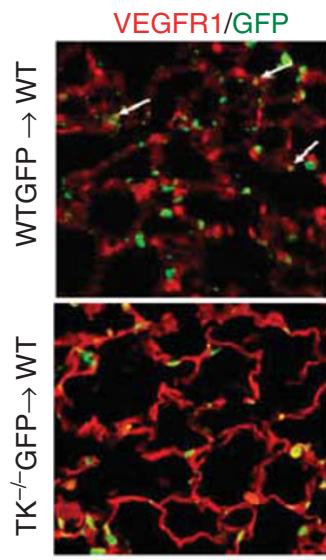

SPA/GFP
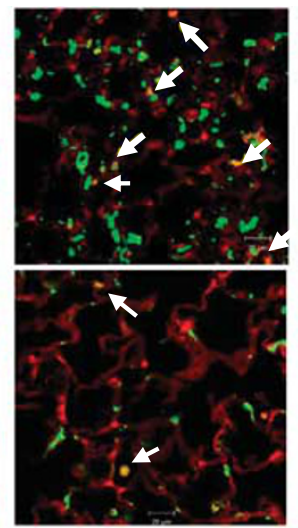

AQP/GFP
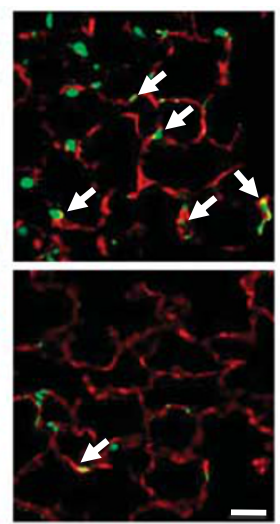

C

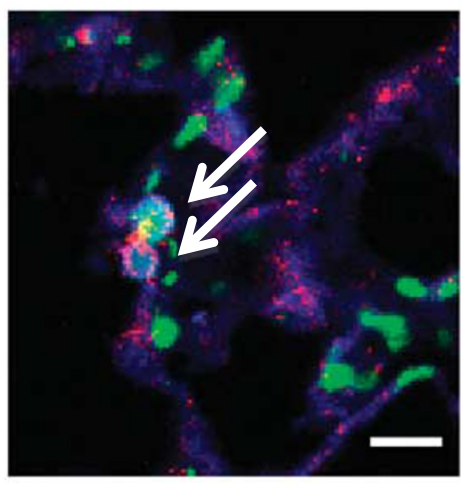

b

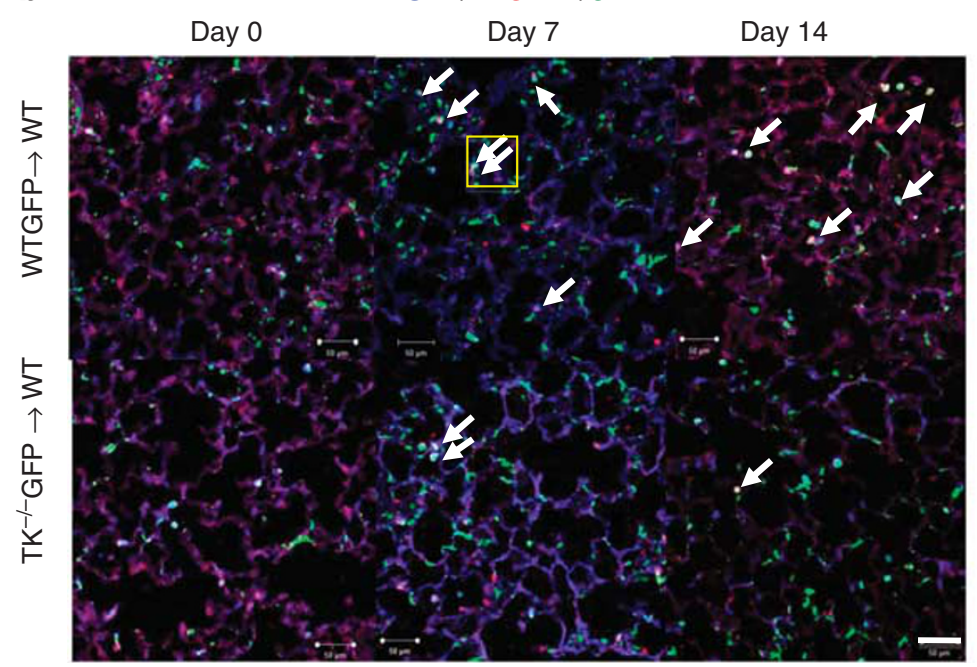

d

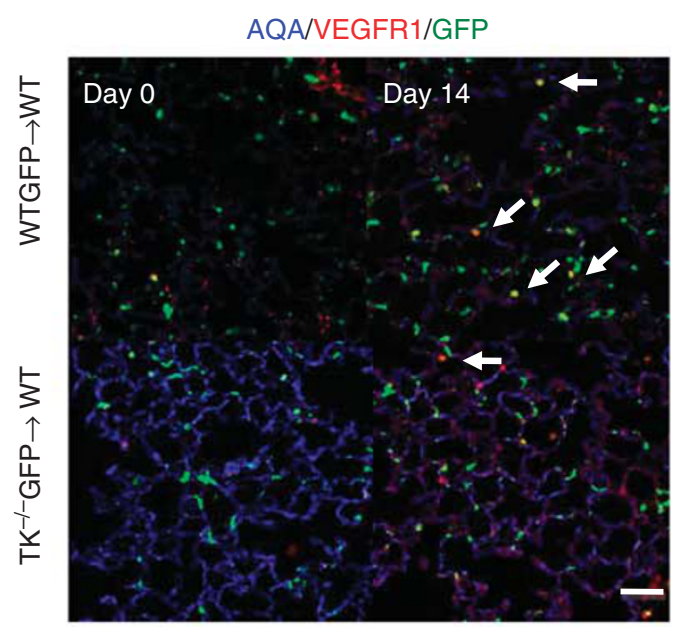

Figure 6 BM-derived VEGFR1 ${ }^{+}$cells induce compensatory lung growth after PNX by increasing the number of ATIls. (a) Immunofluorescence staining of VEGFR1, SPA, AQP, and GFP at day 14 after PNX in right lungs from WT mice transplanted with BM cells from WT or VEGFR1 TK ${ }^{-\prime-}$ transgenic $\mathrm{GFP}^{+}$mice. The arrows indicate VEGFR1 ${ }^{+} / \mathrm{GFP}^{+}, \mathrm{SPA}^{+} / \mathrm{GFP}^{+}$, or $\mathrm{AQP}^{+} / \mathrm{GFP}^{+}$cells. Scale bar $=20 \mu \mathrm{m}$. (b) Immunohistological detection of $\mathrm{SPA}^{+} /$ VEGFR ${ }^{+} / \mathrm{GFP}^{+}$cells (indicated by arrows) at days 0,7 , and 14 after PNX in right lungs from WT mice transplanted with BM cells from WT or VEGFR1 $\mathrm{TK}^{-1-}$ transgenic GFP ${ }^{+}$mice. Scale bar $=50 \mu \mathrm{m}$. (c) Higher magnification of the SPA ${ }^{+} / \mathrm{VEGFR} 1^{+} / \mathrm{GFP}^{+}$cells at day 7 after PNX. Scale bar $=10 \mu \mathrm{m}$. (d) Immunohistological detection of $\mathrm{AQP}^{+} / \mathrm{NEGFR} 1^{+} / \mathrm{GFP}^{+}$cells (indicated by arrows) at days 0 and 14 after PNX in right lungs from WT mice transplanted with BM cells from WT or VEGFR1 $\mathrm{TK}^{-1-}$ transgenic GFP ${ }^{+}$mice. Scale bar $=50 \mu \mathrm{m}$.

the mice with a VEGF neutralizing antibody. These results indicated that overexpression of VEGF is important for compensatory lung growth following after PNX. ${ }^{49}$ PNX causes the remaining lung expansion, and the mechanical strain to the lung leads to activate hypoxia-inducible factor$1 \alpha$ (HIF- $1 \alpha),{ }^{50}$ one of the hypoxia-inducible transcriptional factor of VEGF. Further studies are necessary to determine the involvement of VEGF expression induced by mechanical stretch in lung growth following PNX.

Furthermore, expression of the mRNA encoding VEGFR1 was increased significantly after PNX, whereas the mRNAs encoding VEGFR2 and VEGFR3 were not. These findings were supported by additional experiments in which the remaining right lung weight to body weight ratio after PNX was not affected by inhibition of VEGFR2, but was reduced significantly by knockout of VEGFR1 TK, indicating that VEGF signaling mediated via VEGFR1 TK plays an important role in compensatory lung growth following PNX.

Lung volume is used as an indicator of lung regeneration following PNX. We expected that lung volume as well as remaining lung weight in $\mathrm{TK}^{-1-}$ mice with PNX were smaller than those in WT mice with PNX. Although the results of this study showed that the lung volume in PNX-treated mice at days 7 and 14 was increased as compared with sham-operated mice (Figure 1c), there was no significant difference in lung volume after PNX between WT mice and $\mathrm{TK}^{-1-}$ mice (Figure $3 \mathrm{a}$ ). The reasons why VEGFR1 signaling was not involved in the lung volume fol- 
lowing PNX are not clear; however, the compliance of the lung would affect the lung volume in our employed assessment. In fact, the lung volume is increased not only in compensatory lung growth but also lung emphysema. ${ }^{51}$ Of interest, the VEGF receptor inhibitor, SU5416, induces pulmonary emphysema. ${ }^{48}$ This study also showed that the number of alveoli, which is a popular parameter for pulmonary emphysema, ${ }^{51}$ in $\mathrm{TK}^{-1-}$ mice with PNX was lower than that in WT mice with PNX (Figure 3b). These findings suggest that right remaining lung tissues from $\mathrm{TK}^{-1}$

- mice following left PNX would be emphysematous.

In other words, the lack of VEGFR1 signaling resulted in fragility of alveolar structure and function. Therefore, the lung volume from $\mathrm{TK}^{-1-}$ mice following PNX appears to be comparable to that from WT mice following PNX; however, further studies are needed to solve this question.

VEGF induces remobilization of progenitor cells from the BM. ${ }^{52}$ Stem or progenitor cells are required for alveolar regeneration and repair, and lung growth. Endogenous progenitor cells are also essential to the organization of alveologenesis. VEGFR1 expression has been detected in ATIIs from adult rats, as well as the human fetus. ${ }^{53,54}$ The compensatory lung growth model is a pure model of postnatal lung growth that involves the proliferation of multiple mature endogenous differentiated cell types; however, the roles of stem or progenitor cells in this model have not yet been defined in detail. In early developing primary tumors, the recruitment and incorporation of BM-derived VEGFR2 ${ }^{+}$endothelial progenitor cells into vessels supported by perivascular VEGFR ${ }^{+}$hematopoietic progenitor cells is required for neovascularization. ${ }^{55}$ Furthermore, VEGFR1expressing cells are essential for extravasation and neovascularization, and alveolar macrophages induce the expression of VEGFR1 between days 3 and 14 after PNX. ${ }^{20}$ The release of hematopoietic SCF through MMP-9 activation is also a critical step in the mobilization of VEGFR $1^{+}$cells from the BM. ${ }^{52}$ Here, plasma levels of MMP9 and SCF were significantly lower in the VEGFR1 $\mathrm{TK}^{-1-}$ mice than the WT mice on day 7 after PNX.

We reported previously that BM-derived CXCR $^{+} /$ VEGFR1 ${ }^{+}$cells induce blood recovery from ischemic conditions; ${ }^{32}$ however, here, the numbers of $\mathrm{CXCR}^{+}$/ VEGFR $1^{+}$cells after PNX were comparable in WT and VEGFR1 $\mathrm{TK}^{-1-}$ mice. Furthermore, a previous study demonstrated that SDF-1/CXCR4 signaling contributes to compensatory lung growth, ${ }^{4}$ but compensatory lung growth was not suppressed by injection of mice with a CXCR4 antibody here. In contrast, the numbers of VEGFR $1^{+}$cells were significantly lower in the $\mathrm{TK}^{-1-}$ mice than in the WT mice, suggesting that compensatory lung growth is dependent on VEGFR1 TK signaling but not SDF-1/CXCR4 signaling. Moreover, homing of VEGFR1 ${ }^{+}$cells to the lung tissue was diminished after knockout of VEGFR1 TK, indicating that VEGFR1 signaling plays a role in the recruitment of VEGFR1 + cells into the lung tissue.
Because pulmonary levels of VEGF, a ligand for VEGFR1, are reduced in $\mathrm{TK}^{-1}$ mice with PNX, PNX-induced VEGF in the lung parenchyma appears to promote the recruitment of VEGFR $1^{+}$cells into the lung tissues, consistent with the finding that VEGF induces remobilization of the progenitor cells from BM. ${ }^{51}$

In addition, the findings that the number of $\mathrm{GFP}^{+} \mathrm{BMs}$ in the lung tissue and the weight of the lung were lower in mice that were transplanted with $\mathrm{TK}^{-1-} \mathrm{GFP}^{+} \mathrm{BM}$ than those that were transplanted with $\mathrm{WT} \mathrm{GFP}^{+} \mathrm{BM}$, and that the alveolar sizes did not change significantly during compensatory lung growth, suggest that VEGFR1 TK signaling induces remobilization of VEGFR ${ }^{+}$cells from BM and supports compensatory lung growth.

These findings support the possibility that BM-derived VEGFR $1^{+}$cells are capable of differentiating into alveolar endothelial cells.

Alveolar epithelial cells comprise ATIs and ATIIs that occupy $\sim 96 \%$ and $4 \%$ of the $70 \mathrm{~m}^{2}$ gas exchange area, respectively. The functions of ATIs include water and ion transport, host defense, and tumor suppression. ATIIs are thought to carry out metabolic and other functions necessary to maintain the airspace. Autoradiography after administration of tritiated thymidine suggested that injected ATIs are derived from ATIIs after various types of lung injury and in the developing lung. ${ }^{56}$ Other thymidine labeling studies have also provided some evidence to support the requirement for cell division during the change from the ATII to the ATI phenotype after hyperoxic injury. ${ }^{17,57}$ If ATIIs are damaged, circulating BM-derived cells and endogenous lung cells are candidate sources of newly differentiating cells that can undertake the repair process; however, the precise relationship between these two types of cells is still unclear. To gain insight into this relationship, we performed immunofluorescent analyses of VEGFR1 and SPA. The number of $\mathrm{SPA}^{+} / \mathrm{VEGFR}^{+} / \mathrm{GFP}^{+}$cells was lower in $\mathrm{TK}^{-1-} \mathrm{GFP}^{+}$ $\mathrm{BM}$-transplanted mice than in $\mathrm{WT} \mathrm{GFP}^{+}$BM-transplanted mice. Similar results were also obtained for $\mathrm{AQP}^{+}$/ VEGFR $1^{+} / \mathrm{GFP}^{+}$cells. Although the results of these experiments suggest that VEGFR1 TK signaling induces compensatory lung growth by mobilization of VEGFR $1^{+}$ cells, which increases the number of ATIs and ATIIs, further studies are warranted to clarify the exact mechanism of the increasing accumulation of ATIs and ATIIs after PNX.

Development of therapeutic strategies to repair respiratory capacity in patients with pulmonary function disorders is confounded by unknown mechanisms of lung regeneration. The results presented here show that VEGFR1 TK signaling facilitates compensatory lung growth by recruiting VEGFR $^{+}{ }^{+}$cells from BM. Injecting VEGFR ${ }^{+}$cells that mediate VEGFR1 TK signaling may be a good approach to enhance lung growth following PNX.

Supplementary Information accompanies the paper on the Laboratory Investigation website (http://www.laboratoryinvestigation.org) 


\section{ACKNOWLEDGMENTS}

We thank Yukiko Matsuo, Michiko Ogino, Kyoko Yoshikawa, and Mieko Hamano for their technical assistance.

\section{DISCLOSURE/CONFLICT OF INTEREST}

The authors declare no conflict of interest.

1. Rannels $D E$, Rannels SR. Compensatory lung growth of the lung following partial pneumonectomy. Exp Lung Res 1988;14:157-182.

2. Nijjar MS, Thurlbeck WM. Alterations in enzymes related to adenosine $3^{\prime}, 5^{\prime}$-monophosphate during compensatory growth of rat lung. Eur J Biochem 1980;105:403-407.

3. Cowan MJ, Crystal RG. Lung growth after unilateral pneumonectomy: quantitation of collagen synthesis and content. Am Rev Respir Dis 1975; 111:267-277.

4. Suga A, Ueda K, Takemoto $Y$, et al. Significant role of bone marrowderived cells in compensatory regenerative lung growth. J Surg Res 2012;50022-4804:01957-01959.

5. Nolen-Walston RD, Kim CF, Mazan MR, et al. Cellular kinetics and modeling of bronchioalveolar stem cell response during lung regeneration. Am J Physiol Lung Cell Mol Physiol 2008;294:L1158-L1165.

6. Kotton DN, Ma BY, Cardoso WV, et al. Bone marrow-derived cells as progenitors of lung alveolar epithelium. Development 2001;128:5181-5188.

7. Risau W. Mechanisms of angiogenesis. Nature 1997;386:671-674.

8. Shibuya M. Vascular endothelial growth factor receptor-1 (VEGFR-1/ F(t-1): a dual regulator for angiogenesis. Angiogenesis 2006;9:225-230.

9. Healy AM, Morgenthau L, Zhu X, et al. VEGF is deposited in the subepithelial matrix at the leading edge of branching airways and stimulates neovascularization in the murine embryonic lung. Dev Dyn 2000;219:341-352.

10. Sakurai MK, Lee $\mathrm{S}$, Arsenault DA, et al. Vascular endothelial growth factor accelerates compensatory lung growth after unilateral pneumonectomy. Am J Physiol Lung Cell Mol Physiol 2007;292: L742-L747.

11. Klekamp JG, Jarzecka K, Perkett EA. Exposure to hyperoxia decreases the expression of vascular endothelial growth factor and its receptors in adult rat lungs. Am J Pathol 1999;154:823-831.

12. Varet J, Douglas SK, Gilmartin L, et al. VEGF in the lung: a role for nove isoforms. Am J Physiol Lung Cell Mol Physiol 2010;298:L768-L774.

13. Detmar M, Brown LF, Claffey KP, et al. Overexpression of vascula permeability factor/vascular endothelial growth factor and its receptors in psoriasis. J Exp Med 1994;180:1141-1146.

14. Pham I, Uchida T, Planes C, et al. Hypoxia upregulates VEGF expression in alveolar epithelial cells in vitro and in vivo. Am J Physiol Lung Cell Mol Physiol 2002;283:L1133-L1142.

15. Hiratsuka S, Minowa O, Kuno J, et al. Flt-1 lacking the tyrosine kinase domain is sufficient for normal development and angiogenesis in mice. Proc Natl Acad Sci USA 1998;95:9349-9354.

16. Compernolle V, Brusselmans K, Acker T, et al. Loss of HIF-2alpha and inhibition of VEGF impair fetal lung maturation, whereas treatment with VEGF prevents fatal respiratory distress in premature mice. Nat Med 2002;8:702-710.

17. Adamson IY, Bowden DH. Derivation of type 1 epithelium from type 2 cells in the developing rat lung. Lab Invest 1975;32:736-745.

18. Hoffman AM, Ingenito EP. Alveolar epithelial stem and progenitor cells: emerging evidence for their role in lung regeneration. Curr Med Chem 2012;19:6003-6008.

19. Ding BS, Nolan DJ, Guo P, et al. Endothelial-derived angiocrine signals induce and sustain regenerative lung alveolarization. Cell 2011;147: 539-553.

20. Chamoto K, Gibney BC, Ackermann M, et al. J Alveolar macrophage dynamics in murine lung regeneration. Cell Physiol 2012;227:3208-3215.

21. Mae M, O'Connor TP, Crystal RG. Gene transfer of the vascular endothelial growth factor receptor flt-1 suppresses pulmonary metastasis associated with lung growth. Am J Respir Cell Mol Biol 2005;33:629-635.

22. Been JV, Zimmermann LJ, Debeer A, et al. Bronchoalveolar lavage fluid from preterm infants with chorioamnionitis inhibits alveolar epithelial repair. Respir Res 2009;10:116

23. Yano K, Brown LF, Detmar M. Control of hair growth and follicle size by VEGF-mediated angiogenesis. J Clin Invest 2001;107:409-417.
24. Amano $\mathrm{H}$, Hayashi $\mathrm{I}$, Endo $\mathrm{H}$, et al. Host prostaglandin E(2)-EP3 signaling regulates tumor-associated angiogenesis and tumor growth. J Exp Med 2003;197:221-232.

25. Wedge SR, Ogilvie DJ, Dukes M, et al. ZD6474 inhibits vascular endothelial growth factor signaling, angiogenesis, and tumor growth following oral administration. Cancer Res 2002;62:4645-4655.

26. Scherle W. A simple method for volumetry of organs in quantitative stereology. Mikroskopie 1970;26:57-60.

27. Schneider CA, Rasband WS, Eliceiri KW. NIH Image to ImageJ: 25 years of image analysis. Nat Methods 2012;9:671-675.

28. Staub NC. Pulmonary edema. Physiol Rev 1974;54:678-811.

29. Kamoshita E, lkeda Y, Fujita M, et al. Recruitment of a prostaglandin E receptor subtype, EP3-expressing bone marrow cells is crucial in wound-induced angiogenesis. Am J Pathol 2006;169:1458-1472.

30. Amano $\mathrm{H}$, Ito $\mathrm{Y}$, Ogawa $\mathrm{F}$, et al. Angiotensin II type $1 \mathrm{~A}$ receptor signaling facilitates tumor metastasis formation through P-selectinmediated interaction of tumor cells with platelets and endothelial cells. Am J Pathol 2013;182:553-564.

31. Eshima K, Suzuki H, Shinohara N. Cross-positive selection of thymocytes expressing a single TCR by multiple major histocompatibility complex molecules of both classes: implications for CD4+ versus CD8 + lineage commitment. J Immunol 2006;176:1628-1636.

32. Jin DK, Shido K, Kopp HG, et al. Cytokine-mediated deployment of SDF-1 induces revascularization through recruitment of CXCR4 + hemangiocytes. Nat Med 2006;12:557-567.

33. Lyden D, Hattori K, Dias S, et al. Impaired recruitment of bone-marrowderived endothelial and hematopoietic precursor cells blocks tumor angiogenesis and growth. Nat Med 2001;7:1194-1201.

34. Matsui $\mathrm{Y}$, Amano $\mathrm{H}$, Ito $\mathrm{Y}$, et al. ThromboxaneA2 receptor signaling facilitates tumor colonization through P-selectin-mediated interaction of tumor cells with platelets and endothelial cells. Cancer Sci 2012; 103:1795-1806.

35. Kajstura J, Rota $\mathrm{M}$, Hall SR, et al. Evidence for human lung stem cells. $\mathrm{N}$ Engl J Med 2011;364:1795-1806.

36. Teisanu RM, Chen $\mathrm{H}$, Matsumoto $\mathrm{K}$, et al. Functional analysis of two distinct bronchiolar progenitors during lung injury and repair. Am J Respir Cell Mol Biol 2011;44:794-803.

37. Raoul W, Chailley-Heu B, Barlier-Mur AM, et al. Effects of vascular endothelial growth factor on isolated fetal alveolar type II cells. Am J Physiol Lung Cell Mol Physiol 2004;286:L1293-L1301.

38. Voswinckel $\mathrm{R}$, Motejl V, Fehrenbach $\mathrm{A}$, et al. Characterisation of postpneumonectomy lung growth in adult mice. Eur Respir J 2004;24:524-532.

39. Hsia CC, Herazo LF, Fryder-Doffey $F$, et al. Compensatory lung growth occurs in adult dogs after right pneumonectomy. J Clin Invest 1994;94:405-412.

40. Hsia CC. Signals and mechanisms of compensatory lung growth. J Appl Physiol 2004;97:1992-1998.

41. Ferrara N, Carver-Moore $\mathrm{K}$, Chen $\mathrm{H}$, et al. Heterozygous embryonic lethality induced by targeted inactivation of the VEGF gene. Nature 1996;380:439-442.

42. Gerber HP, Hillan KJ, Ryan AM, et al. VEGF is required for growth and survival in neonatal mice. Development 1999;126:1149-1159.

43. Boussat S, Eddahibi S, Coste A, et al. Expression and regulation of vascular endothelial growth factor in human pulmonary epithelial cells. Am J Physiol Lung Cell Mol Physiol 2000;279:L371-L378.

44. Muratore CS, Nguyen HT, Ziegler MM, et al. Stretch-induced upregulation of VEGF gene expression in murine pulmonary culture: a role for angiogenesis in lung development. J Pediatr Surg 2000;35: 906-912.

45. Fong GH, Rossant J, Gertsenstein M, et al. Role of the Flt-1 receptor tyrosine kinase in regulating the assembly of vascular endothelium. Nature 1995;376:66-70.

46. Brekken RA, Overholser JP, Stastny VA, et al. Selective inhibition of vascular endothelial growth factor (VEGF) receptor 2 (KDR/Flk-1) activity by a monoclonal anti-VEGF antibody blocks tumor growth in mice. Cancer Res 2000;60:5117-5124.

47. Compernolle V, Brusselmans K, Acker T, et al. Loss of HIF-2alpha and inhibition of VEGF impair fetal lung maturation, whereas treatment with VEGF prevents fatal respiratory distress in premature mice. Nat Med 2002:8:702-710.

48. Kasahara Y, Tuder RM, Taraseviciene-Stewart L, et al. Inhibition of VEGF receptors causes lung cell apoptosis and emphysema. J Clin Invest 2000;106:1311-1319. 
49. Sekhon HS, Smith C, Thurlbeck WN. Effect of hypoxia and hyperoxia on postpneumonectomy compensatory lung growth. Exp Lung Res 1993;19:519-532.

50. Zhang Q, Bellotoo DJ, Rakikumar P, et al. Postpneumonectomy lung expansion elicits hypoxia-inducible factor-1 alpha signaling. Am J Physiol Lung Cell Mol Physiol 2007;293:L497-L504.

51. Dunnil MS. Evaluation of a simplemethod of sampling the lung for quantitative histological analysis. Thorax 1964;19:443-448.

52. Hattori K, Dias S, Heissig B, et al. Vascular endothelial growth factor and angiopoietin-1 stimulate postnatal hematopoiesis by recruitment of vasculogenic and hematopoietic stem cells. J Exp Med 2001;193:1005-1101.

53. Hara A, Chapin CJ, Ertsey R, et al. Changes in fetal lung distension alter expression of vascular endothelial growth factor and its isoforms in developing rat lung. Pediatr Res 2005;58:30-37.
54. Lassus $\mathrm{P}$, Turanlahti $\mathrm{M}$, Heikkilä $\mathrm{P}$, et al. Pulmonary vascular endothelial growth factor and Flt-1 in fetuses, in acute and chronic lung disease, and in persistent pulmonary hypertension of the newborn. Am J Respir Crit Care Med 2001;164:1981-1987.

55. Kaplan RN, Riba RD, Zacharoulis S, et al. VEGFR1-positive hematopoietic bone marrow progenitors initiate the pre-metastatic niche. Nature 2005;438:820-827.

56. Cagle PT, Langston C, Goodman JC, et al. Autoradiographic assessment of the sequence of cellular proliferation on post pneumonectomy lung growth. Am J Respir Cell Mol Biol 1990;3: 153-158.

57. Leslie CC, Mc Cormick-Shannon K, Cook JL, et al. Macrophages stimulate DNA synthesis in rat alveolar type II cells. Am Rev Respir Dis 1985;132:1246-1252. 